\title{
LIFESTYLE PECULIARITIES OF YOGA PRACTITIONERS AND NON-PRACTITIONERS
}

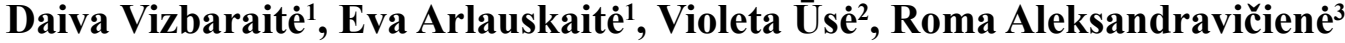 \\ Lithuanian Sports University', Kaunas, Lithuania \\ Lithuanian University of Health Sciences ${ }^{2}$, Kaunas, Lithuania \\ Aleksandras Stulginskis University ${ }^{3}$, Kaunas, Lithuania
}

\begin{abstract}
Background. In the modern world, people are short of time for physical and spiritual education, which may lead to major health problems. Due to passive lifestyle, many of them have a poor body composition, impaired circulation and reduced flexibility, which may contribute to physical disorders and susceptibility to chronic diseases (Chen, Tseng, Ting, \& Huang, 2007). Hypothesis: lifestyle of yoga practitioners is healthier and health evaluation is better compared to those of non- practitioners. The aims of the research were to asses and compare the features of lifestyle and health evaluation of yoga practitioners and non-practitioners.

Methods. The study included middle-aged participants (from 35 to 55 years). A total of 193 people were evaluated, 86 of them were practising yoga. Among these participants, 63 were women, $23-$ men. The other 107 did not practise yoga, 58 of them were women, $43-$ men.

The questionnaire of the lifestyle of Lithuanian adults was used (Grabauskas, Klumbienè, \& Petkevičienè, 2011).

Results. The analysis of the results confirmed the hypothesis proposed at the beginning of the work. Yoga practitioners' nutrition, physical activity, addictions and evaluation of their health was better than those of nonpractitioners.

Conclusion. Yoga practitioners have healthier lifestyle habits, they consume less animal fat, eat more fruits, cereals and cereal-based products. In addition, they are more physically active than non- practitioners, both men and women often exercise alone or in group practice sessions and without yoga they have more kinds of physical activity. A lower prevalence of addictions was observed among them; none of them smoked and they had a lower intake of alcohol beverages compared to yoga non-practitioners. Yoga practitioners are healthier and have a better value of their health and the quality of life.
\end{abstract}

Keywords: yoga, lifestyle, health assessment.

\section{INTRODUCTION}

A ccording to the data of the American Sports and Fitness Association, 90\% of people experience physical, mental or psychological problems on a continuing basis worldwide, and $26 \%$ of population are subjected to stress and strain that are associated with mental and physiological fatigue (Lamb, 2006).

Therefore, it is relevant to search for measures that encourage people to take interest in healthy lifestyle and be physically active. Worldwide, there are many health promotion tools that are of doubtful value and short-lived. However, the guidelines that have undoubted benefits for health have existed over the centuries and have remained unchanged. These guidelines comprise physical activity, healthy diet and peace of mind - all these three constituents are ensured by yoga practise (Saper, Eisenberg, Davis, Culpepper, \& Phillips, 2004).

With an increase in the amount of experienced stress, yoga is becoming a cultural phenomenon 
and it is the worldwide trend of health promotion. Studies have shown that $9 \%$ of all population tried yoga as alternative treatment, and it is growingly becoming popular (Lamb, 2006). The main goal of yoga is to improve general wellbeing. It is aimed not at curing diseases; it teaches people to change their lifestyle and mind. Yoga practise improves, maintains and restores health. It is also valued as stress reduction and considered to be a "cure" against aging. Thus, yoga is regarded as a perspective or assisting treatment for emotional and physiological problems (Emerson, Sharma, Chaudhry, \& Turner, 2009). The aim of the research was to assess and compare the yoga practitioners and non-practitioners lifestyle features and health evaluation.

\section{METHODS}

The study included middle-aged participants (from 35 to 55 years). A total of 193 people were evaluated, 86 of them were practising yoga. Among these participants, 63 were women, $23-$ men. The other 107 did not practise yoga; among them 58 were women, 43 - men.

A questionnaire-based interview included questions about diet, physical activity, harmful habits, and health assessment. The aim of the questions was to determine and compare the peculiarities of lifestyle of yoga practitioners and non-practitioners as well as subjective health assessment. The questionnaire of the lifestyle of Lithuanian adults (Grabauskas et al., 2011) was employed in the study.

The obtained data were analysed using the IBM SPSS Statistics 22.0 package. The significance level was set at $p<.05$, the statistical interdependence was evaluated by chi-square $\left(\chi^{2}\right)$ criteria.

\section{RESULTS}

A comparison of breakfast intake in yoga practitioners and non-practitioners showed statistical significance. Breakfast consumption was pointed out by $87 \%$ of yoga practitioners, while skipping breakfast was reported by $65.3 \%$ of non-practitioners. Yoga practitioners slightly more frequently had dinner, and non-practitioners supper (Figure 1).

A pattern of food intake in women did not show statistical difference. Women yoga practitioners had breakfast $(76.2 \%)$ slightly more frequently compared to $67.2 \%$ of non-practitioners who reported having breakfast (Figure 2).
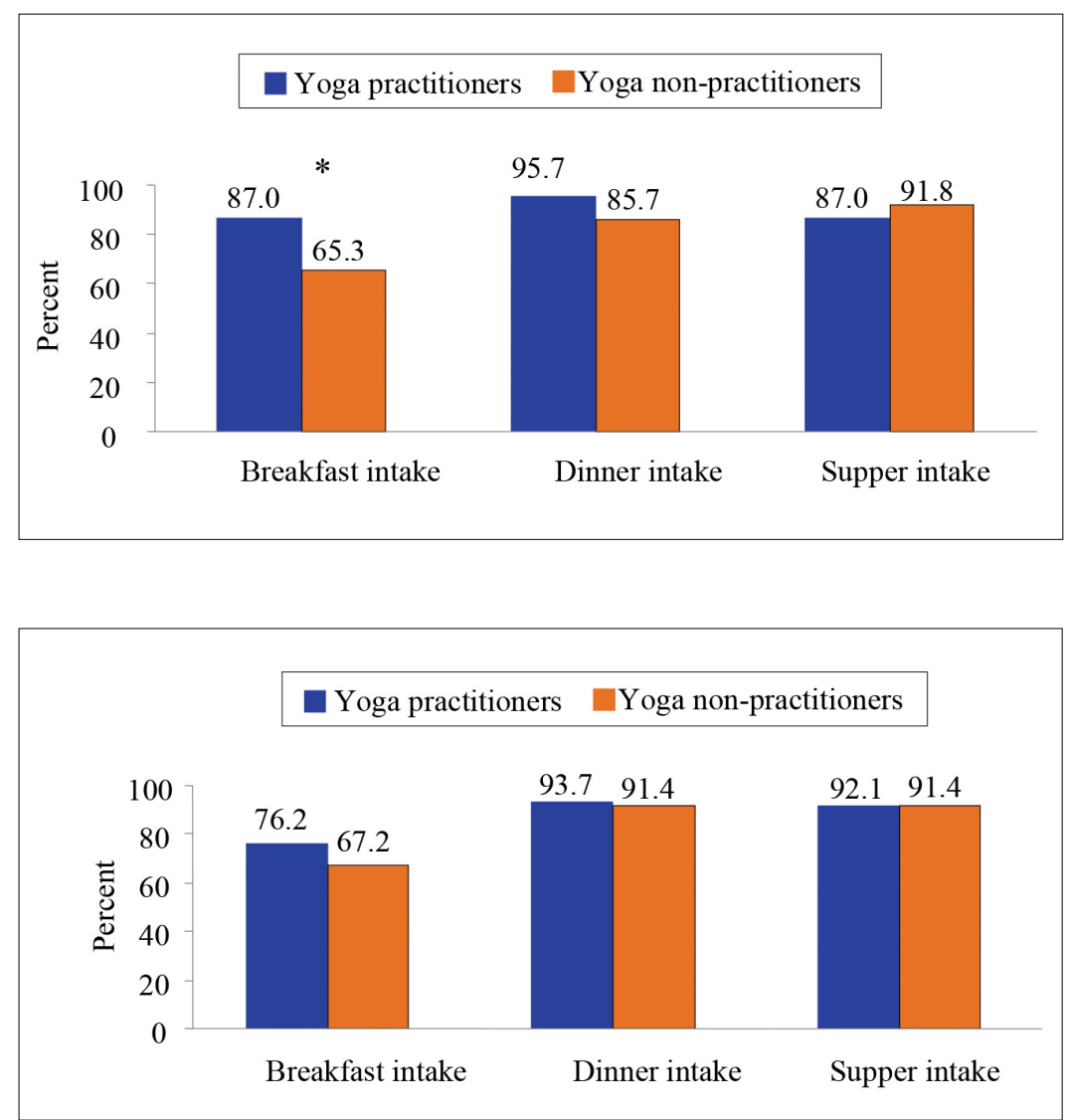

Figure 1. Pattern of food intake in men yoga practitioners and non-practitioners

Note. $x^{2}=4, d f=1,{ }^{*} p<.05$.

Figure 2. Pattern of food intake in women yoga practitioners and non-practitioners 
The regular meal patterns were reported by $60.5 \%$ of yoga practitioners while only $25.2 \%$ of non-practitioners could provide the positive answer. Occasional regular meal pattern was pointed out by $47.7 \%$ of non-practitioners and $29.1 \%$ of yoga practitioners $(p<.05)$.

Type of fat consumed by men did not show statistical difference. Vegetable oil was chosen by $91.3 \%$ of yoga practitioners and $85.7 \%$ of nonpractitioners. Ghee was consumed more frequently by yoga practitioners compared to non-practitioners who had butter (10.2\%) (Figure 3).

The results showed that $94.8 \%$ of women yoga non-practitioners and 58.7 of yoga non-practitioners marked vegetable oil as the most frequent type of oil consumed. Ghee was selected more frequently by yoga practitioners (25.4) versus non-practitioners (14.3\%) (Figure 4).

The analysis of pattern of fruit intake considering yoga practice revealed that the majority $(44.2 \%)$ of yoga practitioners consumed fruits for 6-7 days and 38.4\% - 3-5 days weekly. The pattern of fruit intake in the group of nonpractitioners was as follows: $30.8 \%$ had fruits for 1-2 days, $29.5 \%$ - for 3-7 days. Gender difference showed no statistical significance (Figure 5).

Men yoga practitioners more frequently consumed cereals or grains compared to
Figure 3. Pattern of fat intake in men yoga practitioners and nonpractitioners according to the type of fat

Note. $x^{2}=5, d f=3, p>.05$.

Figure 4. Pattern of fat intake in women yoga practitioners and nonpractitioners according to type of fat

Note. $x^{2}=22, d f=3, p<.05$.

Figure 5. Pattern of fruit intake in women yoga practitioners and nonpractitioners

Note. $x^{2}=13, d f=3, p<.05$.
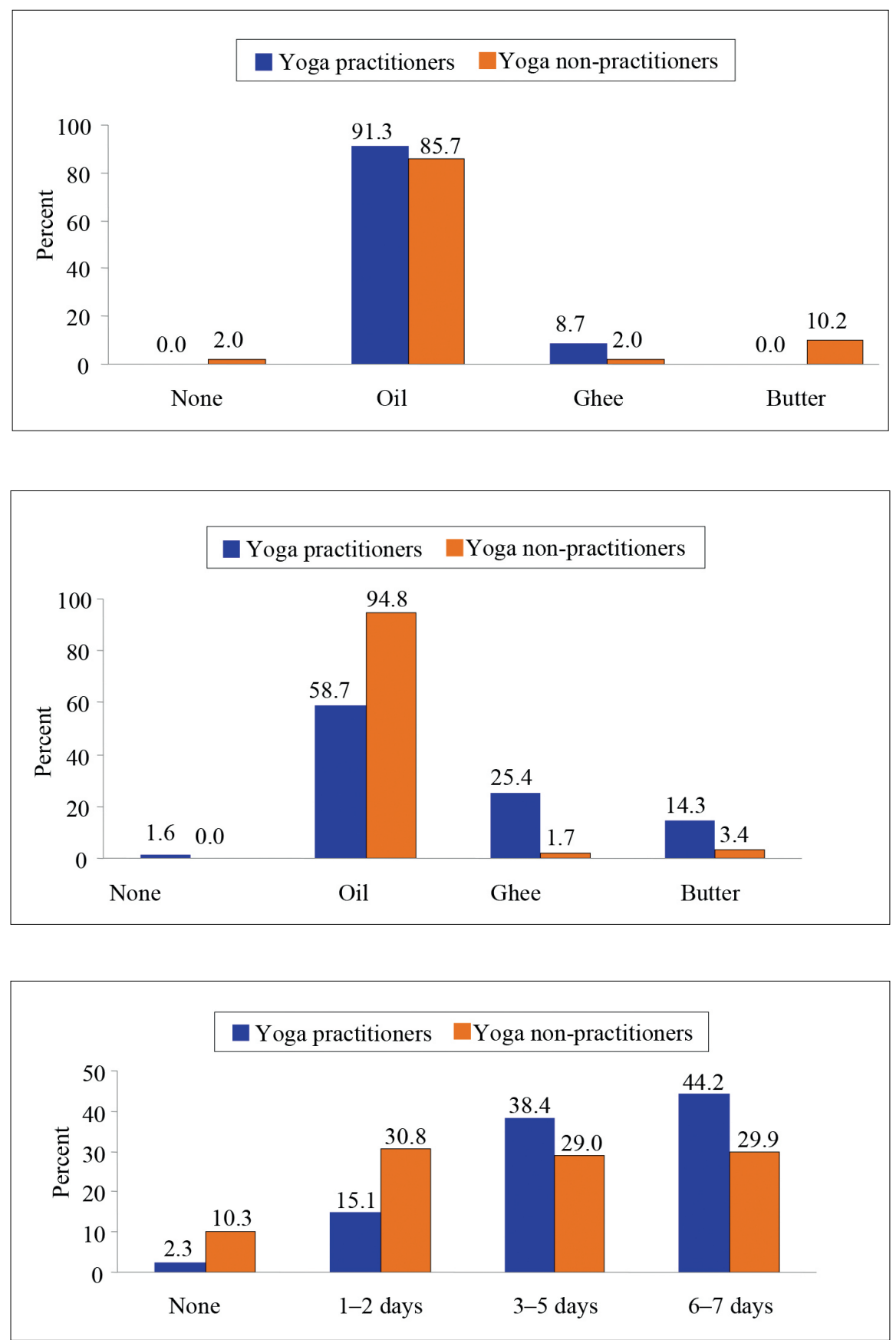

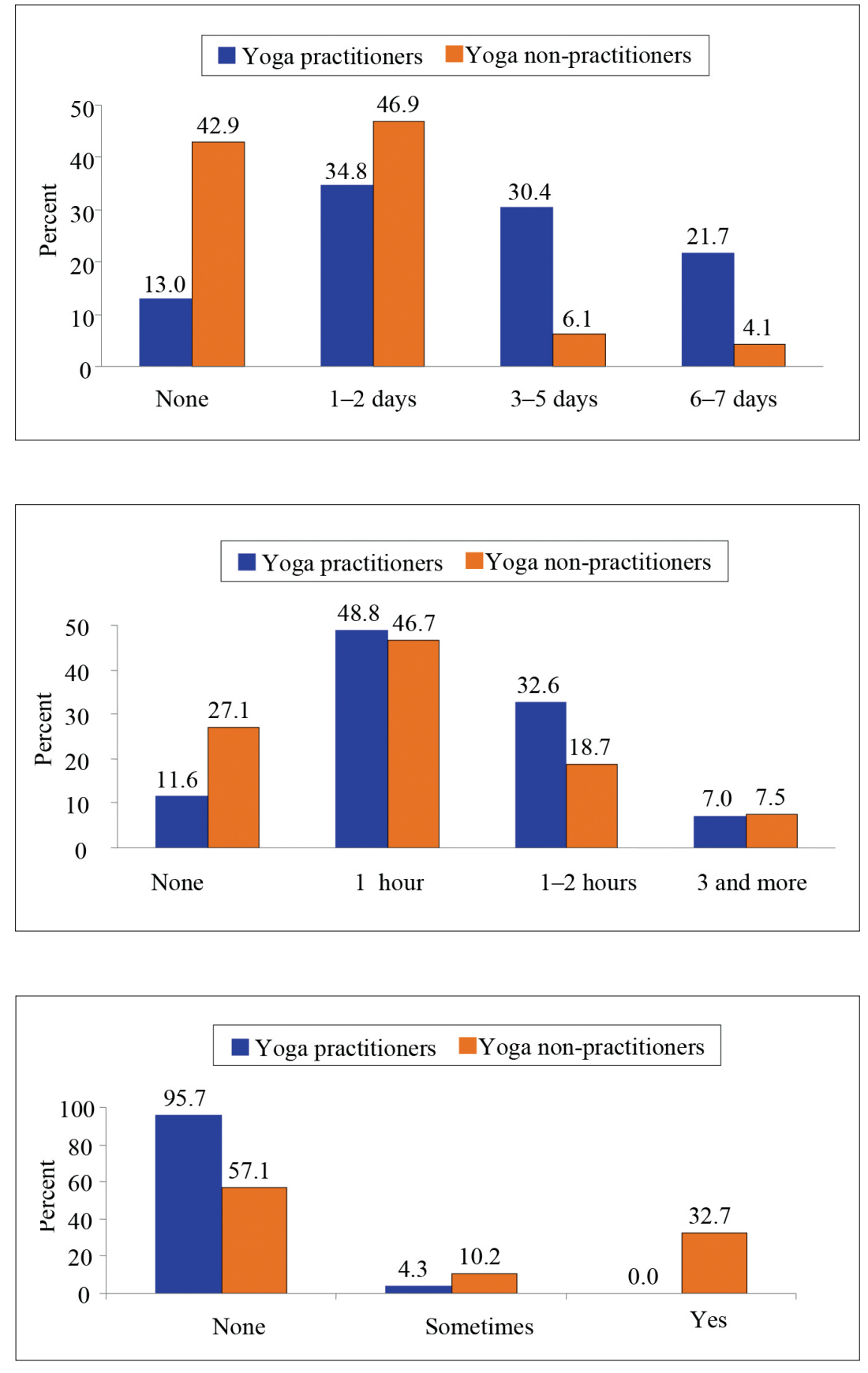

Figure 6. Pattern of cereals or grain consumption in men yoga practitioners and non-practitioners

Note. $x^{2}=16, d f=3, p<.05$.

Figure 7. Pattern of time devoted to physical activity in groups of yoga practitioners and non-practitioners

Note. $x^{2}=9, d f=3, p<.05$.

Figure 8. Pattern of smoking in the group of men yoga practitioners and nonpractitioners

Note. $x^{2}=12, d f=2, p<.05$. non-practitioners. Cereal consumption in the group of yoga practitioners had the following pattern: $34.8 \%$ had cereals $1-2$ days weekly, $30.4 \%-3-5$ days, and $21.7 \%-6-7$ days; in the group of non-practitioners $-46.9 \%$ had cereals 1-2 days weekly, and $42.9 \%$ reported not having cereals at all (Figure 6).

The analysis of time devoted to physical activity revealed that $48.8 \%$ of yoga practitioners and $46.7 \%$ of non-practitioners had an hour of physical activity. Yoga practitioners (32.65) had $1-2$ hours per day, $11.6 \%$ - did not have at all. Only $18.7 \%$ of non-practitioners had 1-2 hours, and
$27.1 \%$ of respondents reported not devoting time to physical activity at all. Gender differences showed no statistical significance (Figure 7).

The research determined that the majority of men in the group of yoga practitioners did not smoke, while among non-practitioners, $57.1 \%$ were non-smokers, and $32.7 \%$ reported smoking on regular basis (Figure 8).

Non-smoking was reported by $98.4 \%$ of yoga practitioners and $74.1 \%$ of non-practitioners; $20.7 \%$ of non-practitioners smoked regularly (Figure 9).

The majority of yoga non-practitioners including $86.2 \%$ of women and $85.7 \%$ of men consumed 
Figure 9. Pattern of smoking in the group of women yoga practitioners and nonpractitioners

Note. $x^{2}=16, d f=2, p<.05$.
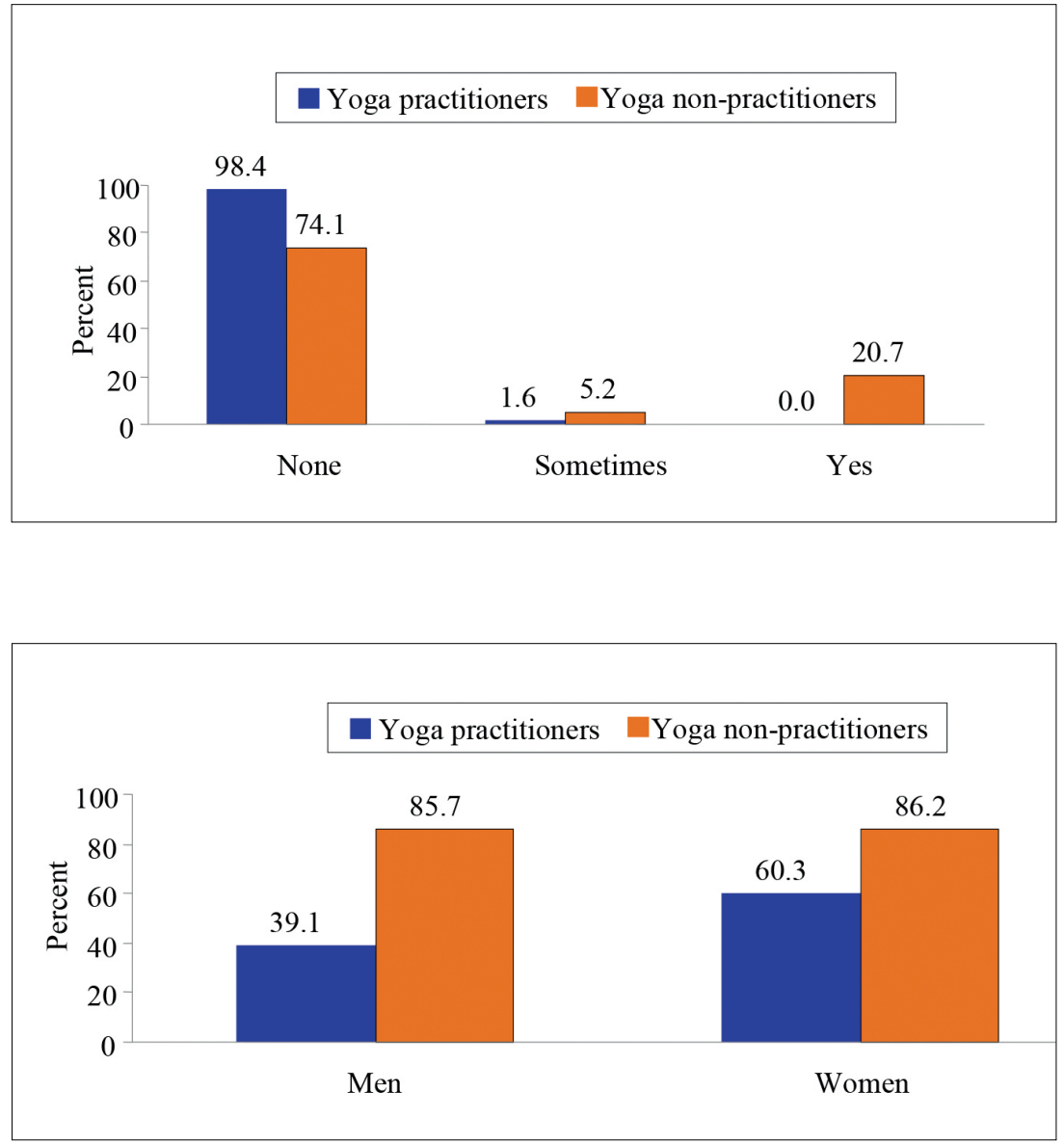

\begin{abstract}
Figure 10. Pattern of alcohol consumption in yoga practitioners and non-practitioners
\end{abstract}

Note. $x^{2}=23, d f=1, p<.05$.

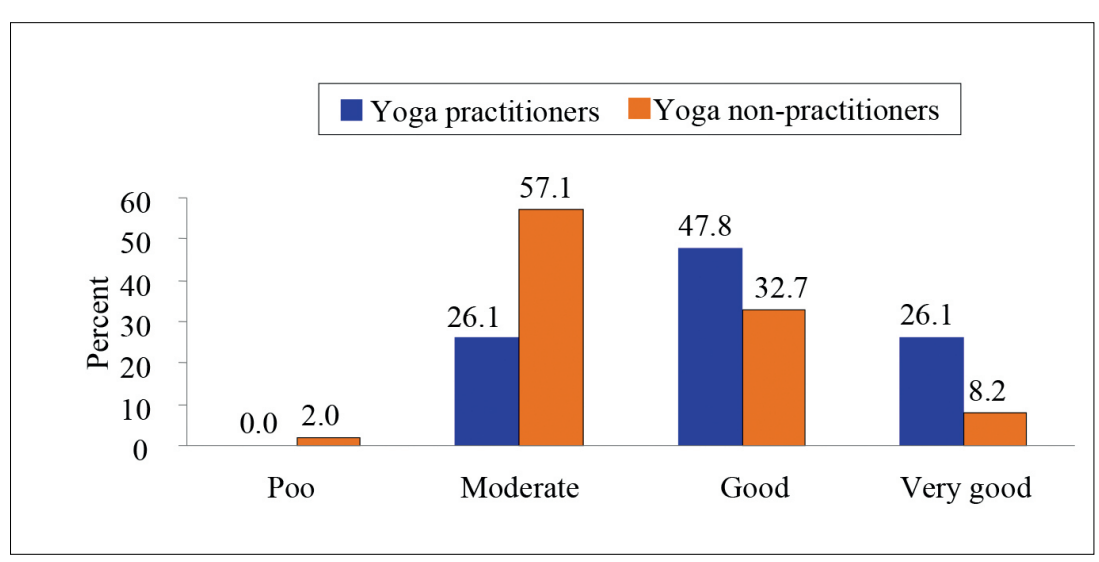

Figure 11. Pattern of subjective self-rated health in men yoga practitioners and nonpractitioners

Note. $x^{2}=8, d f=3, p<.05$. good - by $32.7 \%$, and very good - by $8.2 \%$ of respondents (Figure 11).

The majority of self-reporting women evaluated their health as good $-71.4 \%$ of yoga practitioners and $51.7 \%$ of non-practitioners. Moderate health was self-reported by $36.2 \%$ of non-practitioners and $7.9 \%$ of yoga practitioners; very good - by $20.6 \%$ of yoga practitioners and $6.9 \%$ of non-practitioners (Figure 12). 


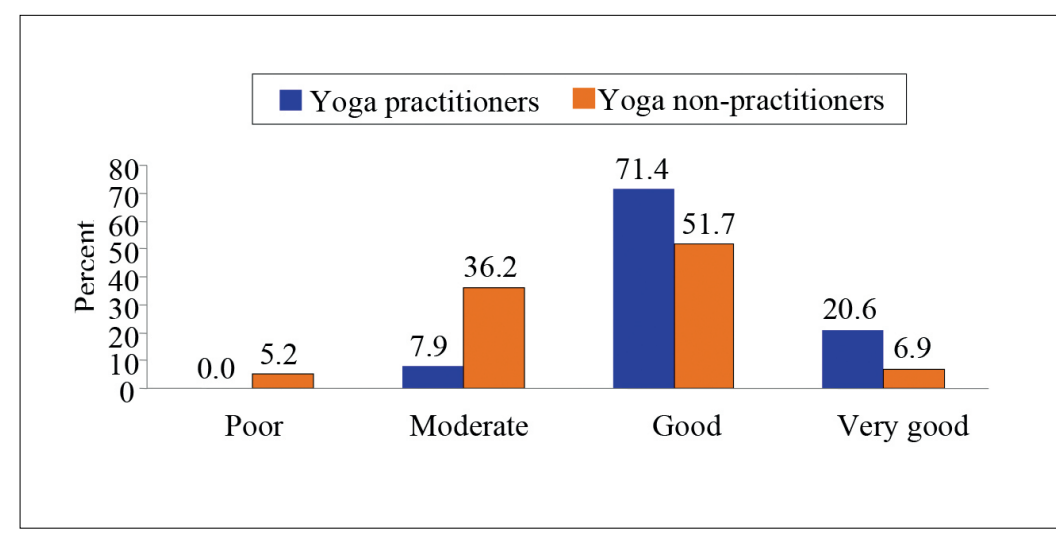

Figure 12. Pattern of subjective self-rated health in women yoga practitioners and nonpractitioners

Note. $x^{2}=20, d f=3, p<.05$.

\section{DISCUSSION}

In his study on regular eating pattern, Norkus found out that only half of Lithuanian people had regular food intake: three times per day $(42 \%$ of women, $57 \%$ of men) (Norkus, 2012). According to our data, regular eating pattern did not correspond with Norkus' study results; yoga practitioners (93\%) and non-practitioners (84.1\%) had meal intake 3-5 times per day. The data of the research show that yoga practitioners as well as non-practitioners have meal intakes three times per day; however, they have breakfast and dinner on regular basis.

A study on people's dieting patterns found that fatty foods, particularly animal products, were predominant in the ration of both genders. Carbohydrate consumption was very low, and only $20 \%$ of people used fruit and vegetables (Barzda, Bartkevičiūtè, Abaravičius, Stukas, \& Šatkute, 2009). Therefore, the consumption of products high in energetic value, amounts of fats and sugar is becoming more frequent, while intake of cereal grains, fruits and vegetables is dramatically reducing (Grabauskas, 2012). In our research the similar trend is found only among yoga non-practitioners. The excessive amount of meat consumption is in men $-44.9 \%$ have meat 3-5 days. A low intake of fruits is observed $30.8 \%$ of the respondents had them only 1-2 days per week as well as a very low amount of grains per week; most of the subjects do not use grains or have them 1-2 days per week. However, among yoga practitioners these rates significantly differ mostly men use meat $1-2$ days (52.2\%), and $34.8 \%$ do not consume meat at all; women mostly do not consume meat $(49.2 \%)$ or have a meat intake $1-2$ days per week (41.3\%). Mostly vegetables were consumed 3-5 days, and fruit $-6-7$ days per week. Cereal grains were consumed 1-7 days per week.

Our results show that yoga practise affects people's attitudes about the regularity of eating, proper nutrition that involves low amounts of animal products, high intake of fruits, vegetables and cereal grains.

According to the guidelines of the World Health Organization, an adult should be physically active at least for $30 \mathrm{~min}$ per day (WHO, 2007). In our research, the data of the respondents are in concordance with the guidelines, but yoga practitioners devote more time for exercising.

According to Grabauskas' (2012) study, almost $51.6 \%$ of Lithuanians never exercise, and during their leisure time they are physically passive. The results of our study confirm these data: $53 \%$ of men and $48.3 \%$ of women never exercise. Among yoga practitioners, $17.3 \%$ of men and $14.2 \%$ of women are physically inactive.

We also have found that yoga practitioners also preferred other kinds of activities, such as walking (66.3\%), exercising (36\%), swimming (11.6\%), or cycling (17.4\%).

The similar data were received in Penman's study, according to which yoga practitioners were physically more active because they devoted more time for walking, swimming and cycling (Penman, Cohen, Stevens, \& Jackson, 2012).

Therefore, yoga practitioners are more physically active, and yoga by itself encourages people's physical activity.

We also have found that $32.7 \%$ of men and $20.7 \%$ of women yoga non-practitioners regularly smoked. These data are almost in concordance with 
other research results; according to Astrauskienè at al., $40 \%$ of men and $20 \%$ of women smoked on regular basis (Astrauskiene, Gasperas, \& Jasaitis, 2009).

Penman found that people who started yoga practice ceased smoking $(80 \%)$ and using alcohol beverages (23\%) (Penman, Cohen, Stevens, \& Jackson, 2012). The results of our research show that $69.6 \%$ of men and $30.2 \%$ of women used to smoke regularly. Thus, yoga practice may encourage people to cease smoking.

In Astrauskiene at al.'s (2009) study about alcohol intake, gender difference showed no statistical significance. Alcohol consumption was reported by $69 \%$ of men and $56 \%$ of women. According to our research, gender difference showed no statistical significance among yoga non-practitioners: $85.7 \%$ of men and $86.2 \%$ of women consumed alcohol beverages. However, yoga practitioners, particularly, men, reported lower amounts of alcohol intake (39.1\% of men and $60.3 \%$ of women, respectively).

According to the study on the Lithuanian adults' lifestyle in 2010, good self-rated health was reported by $52 \%$ of women and $53 \%$ of men (Grabauskas et al., 2011). Considering gender, our research data correspond to the data in Grabauskas et al.'s study only in female group (51.7\%), however, only $32.7 \%$ of men self-reported health as good. The data of yoga practitioners show that not only their health is better, but also they self-reported having good health (47.8\% of men and $71.4 \%$ of women). The same data were obtained when evaluating the quality of life. The frequency of yoga practice at home favourably predicted $(p<.001)$ : mindfulness, fruit and vegetable consumption, vegetarian status and vigour. Specifics components of yoga practice improve health behaviours or lifestyle-related health conditions (Ross et al., 2012).

According to the survey of the middle-aged Lithuanian people, $24 \%$ of them reported sufficient physical activity, and $76 \%$ think that they are not enough physically active (Maciulevičienè \& Kardelis, 2006). These data correspond with our results only in the group of men yoga nonpractitioners $(26.5 \%)$ and women yoga practitioners (25.4\%). The majority of men yoga practitioners (39.1\%) think that they are sufficiently physically active.

According to Grabauskas at al., the rate of obesity is growing due to the predominance of sedentary lifestyle. In Lithuania, $19.7 \%$ of people are obese, and 55\% are overweight (Grabauskas et al., 2011).

Our research shows that only the data of yoga non-practitioners are in concordance with Grabauskas at al.'s study (obesity in $14.3 \%$, being overweight in $51 \%$ of the research participants). Weight is normal in the majority of women and yoga practitioners.

The analysis of the data confirms the hypothesis proposed at the beginning of the research.

\section{CONCLUSION}

Yoga practitioners have healthier lifestyle habits, they consume less animal fat, eat more fruits, cereal grains. Also, they are more physically active than non-practitioners. The lower prevalence of addictions is among yoga practitioners; none of them smoke and have a lower intake of alcohol beverages compared to yoga non-practitioners. Yoga practitioners are healthier and have a better value of their health and the quality of life.

\section{REFERENCES}

Astrauskienè, A., Gasperas, V., \& Jasaitis, E. (2009). Psichoaktyviuju medžiagu vartojimo paplitimas Lietuvoje 2004 ir 2008 metais (Narkotikų kontrolès departamento, prie Lietuvos respublikos ministerijos, užsakomojo tyrimo ataskaita). Vilnius: Europos narkotikų ir narkomanijos stebėsenos centras.

Barzda, A., Bartkevičiūtè, R., Abaravičius, J. A., Stukas, R., \& Šatkute, R. (2009). Suaugusių Lietuvos žmonių faktinès mitybos tyrimas ir vertinimas. Medicinos teorija ir praktika, 1, 53-58.
Chen, K. M., Tseng, W. S., Ting, L. F., \& Huang, G. F. (2007). Development and evaluation of a yoga exercise programme for older adults. Journal of Advanced Nursing, 57, 432-441. doi: 10.1111/j.13652648.2007.04115.x

Emerson, D., Sharma, R., Chaudhry, S., \& Turner, J. (2009). Yoga therapy practice. Trauma- sensitive Yoga: Principles, practice, and research. International Journal of Yoga Therapy, 19, 123-128. 
Grabauskas, V., Klumbienè, J., \& Petkevičienė, J. Norkus, A. (2012). Sveika gyvensena Lietuvos studentu (2011). Suaugusiu Lietuvos žmoniu gyvensenos tyrimas, populiacijoje: edukacinis diagnostinis aspektas. 2010. (Kauno medicinos universiteto Biomedicinos Daktaro disertacija, socialiniai mokslai, edukologija, tyrimų instituto užsakomoji tyrimo ataskaita). Kaunas: LSMU.

Grabauskas, V. (2012). Lètinès neinfekcinès ligos sveikatos politikos kontekste: Lietuvos patirtis. Sveikatos forumo metines konferencijos (Vilnius, 2012 m. lapkričio 29, 30 d.)

Lamb, T. (2006). Yoga statistics and demographics. The Journal of International Association of Yoga Therapists, 2, 2-29.

Maciulevičienė, E., \& Kardelis, K. (2006). Kauno vidutinio amžiaus gyventojų fizinio aktyvumo laisvalaikiu raiška ir jo sąsajos su socialiniais-demografiniais veiksniais. Ugdymas. Küno kultūra. Sportas, 3(62), 29-35. 07 S. Šiauliai: Šiaulių universitetas.

Penman, S., Cohen, M., Stevens, P., \& Jackson, S. (2012). Yoga in Australia: Results of national survey. International Journal of Yoga, 5(2), 92-101.

Ross, A., Friedmann, E., Bevans, M., \& Thomas, S. (2012) Frequency of yoga practice predicts health: Results of a national survey of yoga practitioners. Evidence-Based Complementary and Alternative Medicine, Volume 2012 (2012), 10.

Saper, R., Eisenberg, D., Davis, R., Culpepper, L., \& Phillips, R. (2004). Prevalence and patterns of adult yoga use in the United States: Results of a national survey. Journal of Alternative Therapies Health and Medicine, 10, 44-48.

Corresponding author Daiva Vizbaraitè Lithuanian Sports University Sporto str. 6, LT-44221 Kaunas Lithuania Tel. +370 302671

E-mail daiva.vizbaraite@1su.lt 